NBSIR 76-1008

\title{
Energy Conservation Through the Facilitation of Increased Blended Cement Use
}

Paul Wencil Brown

James R. Clifton

Geoffrey Frohnsdorff

Institute for Applied Technology

National Bureau of Standards

Washington, D. C. 20234

February 1976

Interim Report

July 1 - December 1, 1975

Prepared for

Energy Research and Development Administration

20 Massachusetts Avenue

Washington, D. C. 20545 



\section{ENERGY CONSERVATION THROUGH \\ THE FACILITATION OF INCREASED \\ BLENDED CEMENT USE}

Paul Wencil Brown

James R. Clifton

Geoffrey Frohnsdorff

Institute for Applied Technology

National Bureau of Standards

Washington, D. C. 20234

February 1976

Interim Report

July 1-December 1, 1975

Prepared for

Energy Research and Development Administration

20 Massachusetts Avenue

Washington, D. c. 20545

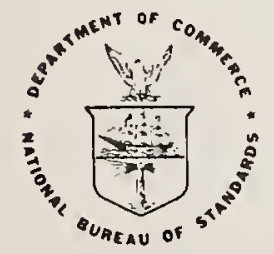

U.S. DEPARTMENT OF COMMERCE, Elliot L. Richardson, Secretary James A. Baker, III, Under Secretary

Dr. Betsy Ancker-Johnson, Assistant Secretary for Science and Technology

NATIONAL BUREAU OF STANDARDS, Ernest Ambler, Acting Director 

ABSTRACT.$\ldots \ldots \ldots \ldots \ldots \ldots \ldots \ldots \ldots \ldots \ldots \ldots \ldots \ldots \ldots \ldots \ldots \ldots \ldots \ldots \ldots \ldots \ldots \ldots$

1. INTRODUCTION $\ldots \ldots \ldots \ldots \ldots \ldots \ldots \ldots \ldots \ldots \ldots \ldots \ldots \ldots \ldots \ldots \ldots \ldots \ldots \ldots \ldots \ldots$

2. BLENDED CEMENT PRODUCTION AND UTILIZATION. $\ldots \ldots \ldots \ldots \ldots \ldots \ldots \ldots \ldots \ldots \ldots \ldots \ldots \ldots$

3. OBSTACLES TO THE INCREASED USE OF BLFNDED CEMENT $\ldots \ldots \ldots \ldots \ldots \ldots \ldots \ldots \ldots \ldots \ldots \ldots$

3.1 Geographical Limitations to the Utilization of Slag and Fly Ash in Cement.. 7

3.2 Specification Limitations to Slag and Fly Ash Utilization in Cement........ 9

3.3 Standard Tests for Blended Cements............................. 12

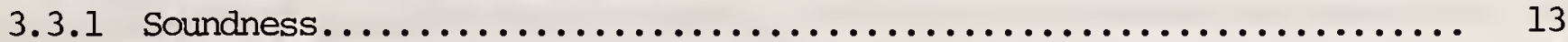

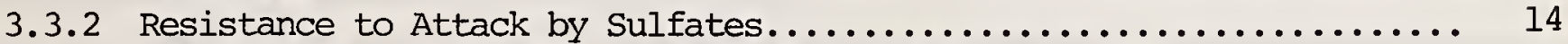

3.3.3 Reactivity with Alkali-Susceptible Aggregates................ 15

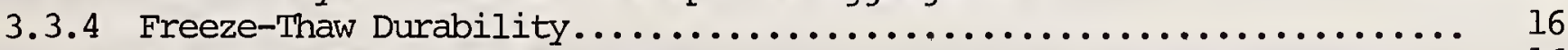

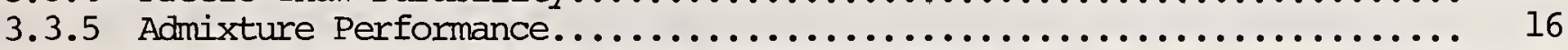

3.3.6 Fly Ash and Slag Contents of Blended Cements.................. 17

3.3.7 Strength Gains of Blended Cement Concretes..................... 17

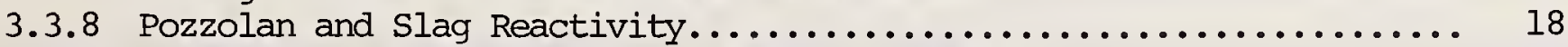

3.3.9 Protection of Reinforcing Bars from Corrosion................ 18

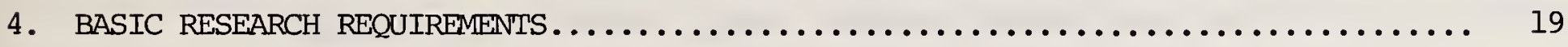

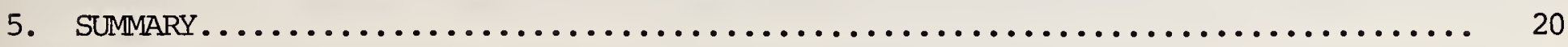

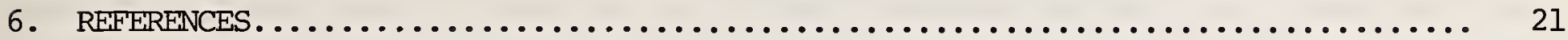


About $95 \%$ of the cement produced in the United States is portland cement and its manufacture requires about $2 \%$ of the energy consumed annually in the nation's industrial processes. The production of blended cements containing substantial amounts of fly ash or blast furnace slag and their substitution for portland cement appears attractive from the standpoint of energy conservation. While production and utilization of blended cements in other industrialized countries is extensive, blended cements account for less than $1 \%$ of the total cement production in the U.S. The reasons for the small U.S, production of blended cements are discussed in the contexts of standards revision and the need for the development of additional data as a basis for this revision.

Keywords: Blast furnace slag; blended cements; energy conservation; fly ash. 
Hydraulic cement concrete is the most widely used man-made building material in the world. About 700 million tons $\left(6.5 \times 10^{11} \mathrm{~kg}\right)$ are used annually in the United States alone*. The binder in most concrete placed in the U.S. is portland cement. Its manufacture uses about 564 trillion Btu $\left(6 \times 10^{17} \mathrm{~J}\right)$ [2] or about $2 \%$ of the energy consumed directly in the nation's industrial processes**. Although the energy used per unit weight of portland cement is low compared to most other building materials (table 1), the cost of energy to produce cement as a percentage of its market value is high (table 2). Because the large quantity of cement produced annually in the U.S., 85 million tons [4], requires a large energy consumption, it is in the national interest to reduce the energy requirement for cement manufacture.

For most purposes, portland cements can be substituted by blended cements which require less energy to manufacture. Blended cements are made by intergrinding reactive additives such as certain industrial wastes or by-products with portland cement clinker***. The most important of these reactive additives are fly ash from coal burning power plants and granulated blast furnace slag.

About 95\% of the cements used in the U.S. fall into 5 main types which are defined by ASTM standard specification C150-74 [5]. Table 3 lists the estimated amounts of each of these types produced annually in the U.S. and indicates the suitability for extensive substitution by a blended cement if appropriate standards were available to ensure satisfactory performance. As may be seen, blended cements may potentially be extensively substituted for each type of portland cement listed with the exception of type III, high early strength cement. This belief is based largely on successful foreign experience and considerations of cement chemistry. However, as will be discussed later, there is a need for additional data with regard to certain specific properties or applications before the full potential uses of blended cements can be achieved in the U.S.

* Calculation based on concrete with an average cement content of $12 \%$ [1].

** Calculation based on a national energy consumption of 72,200 trillion Btu $\left(7.3 \times 10^{19} \mathrm{~J}\right)$ in 1972 [3].

***For the purposes of this paper, blended cements are considered to contain significant amounts, at least $10 \%$, of these additives, but their compositions are not restricted to the types defined by ASTM specifications [5] . 
TABLE 1. Energy Requirements for Manufacture of Some Basic Building Materials [6]

Material

Aluminum

Copper

Steel

Polystyrene

PVC

Paper and Board

Glass

Cement*

Concrete*
Tons (kg) of Oil/Ton (kg) of Basic Material

5.6

1.2

1.0

3.2

2.0

1.4

0.5

0.18

0.02

*Calculated assuming an average energy requirement of $7,400,000 \mathrm{Btu} / \mathrm{ton}\left(8.2 \times 10^{6} \mathrm{~J} / \mathrm{kg}\right)$ of cement produced [1].

TABLE 2. Cost of Purchased Energy as a Percentage of the Value of Shipments of Selected Building Materials [7]

Product

Hydraulic Cement

Building Paper and Board

Structural Clay Products

Flat Glass

Plastics

Concrete, Gypsum \& Plaster Products

Roofing Materials

Cut Stone
Energy Cost $\%$ of Value

15.6

7.6

7.4

4.3

3.1

2.7

2.6

2.2 
TABLE 3. Portland Cement Types, Characteristics and Possibilities for Substitution by Blended Cements

\begin{tabular}{|c|c|c|c|c|}
\hline $\begin{array}{l}\text { ASTM } \\
\text { Cement }\end{array}$ & $\begin{array}{c}\text { Purpose or } \\
\text { Distinguishing }\end{array}$ & $\begin{array}{l}\text { imated } \\
\text { int Used, }\end{array}$ & $\begin{array}{r}\text { May be } \\
\text { Blended }\end{array}$ & $\begin{array}{l}\text { Substituted by a } \\
\text { Cement containing }\end{array}$ \\
\hline & Characteristics & x $10^{6}$ /year & Slag & Fly Ash \\
\hline I & General Purpose & 70 & yes & yes \\
\hline II & Moderate Sulfate Resistance & & yes [8] & yes \\
\hline & Moderate Heat of Hydration & 10 & yes [8] & yes \\
\hline & Low Alkali Content & . & yes & yes \\
\hline III & High Early Strength & 2.9 & no & no \\
\hline IV & Low Heat of Hydration & $<1$ & yes & yes \\
\hline $\mathrm{V}$ & High Sulfate Resistance & $<1$ & yes & yes \\
\hline
\end{tabular}

*One ton is equivalent to about $907 \mathrm{~kg}$. 
The cement manufacturing process may be divided into 3 parts: raw materials processing, pyroprocessing and finish grinding. Table 4 lists the approximate energy requirements for each of these. The introduction of suitable reactive waste materials, such as fly ash or blast furnace slag, into the cement making process can result in large energy savings. Fly ash is produced as finely divided particles, therefore little grinding is required. Because fly ash is pozzolanic, no further pyroprocessing is necessary, and this material may be mixed with portland cement clinker in the final grinding phase of the cement manufacturing process. Like fly ash, many slags are reactive in the presence of water and portland cement and only require grinding to cement fineness. Slags, however, tend to be somewhat more difficult to grind than portland cement clinker making final grinding more energy intensive. Nevertheless, compared with the manufacture of portland cements, the manufacture of blended cements requires less energy roughly in proportion to the amount of the interground fly ash or blast furnace slag.

\section{BLENDED CEMENT PRODUCTION AND UTILIZATION}

Although the cements used in the U.S. are almost exclusively portland cements, many other industrialized countries use large quantities of blended cements. For example, approximately $60 \%$ of the weight of cements produced in France is blended cements [9]. The Soviet Union produces about 30 million tons of slag portland cement annually accounting for about $1 / 3$ of its cement production [10]. About $20 \%$ of the cement produced in South Africa is slag cement with its production limited only by the amount of slag produced while in Japan a similar situation exists with regard to fly ash. Table 5 lists the amounts of cement and concrete and the amounts of slag and fly ash produced and used in cement and concrete in the U.S. each year. While the building practices in the United States sometimes require the use of relatively rapidly hardening portland cements, blended cements could, as table 3 indicates, be substituted for portland cements in most areas of general use with a significant saving in energy. For example, Type II portland cement, whether selected for its moderate resistance to sulfate attack or its moderately low heat of hydration, could probably be replaced almost completely by blended cements. Further, some blended cements produce concretes 
TABLE 4. Energy Consumption in Portland Cement Manufacture [1]

\section{Process}

Raw Materials Processing:

Quarrying and Crushing

Drying

Initial Grinding

Pyroprocessing (kiln fuel)

Finish Grinding
Percent of Total Energy

1.5

4.3

$3.8-4.3$

79.7

7.0

TABLE 5. Annual U.S. Concrete, Cement, Fly Ash and Slag Production and Utilization

\section{Material}

Portland Cement Concrete

Portland Cement (U.S. Production)

Portland Cement (Imported)

Fly Ash Collected

Fly Ash Used in ASTM Type IP Blended Cement

Type IP Blended Cement Containing Fly Ash**

Blast Furnace Slag

Type IS Blended Cement Containing Slag

Slag as Aggregate in Concrete
Production or Utilization in tons $\times 10^{6 *}$ $\underline{\text { Reference }}$

8

40

.4

$<1$

$\star \star \star$

25

\footnotetext{
* One ton is equivalent to about $907 \mathrm{~kg}$.

** Exclusive of cement produced by mixing fly ash with portland cement at the construction site.

*** Estimated output of the cement companies which produce type IP cement. $* * * *$ Estimated output of the cement companies which produce type IS cement.
} 
with higher ultimate strengths than otherwise similar concrete with portland cement [11]. Published information [12-16] on blended cements also suggests they can bring improvement in other important properties of concrete (e.g. permeability, acid resistance, sulfate resistance, etc.).

\section{OBSTACIES TO THE INCREASED USE OF BLENDED CEMENTS}

Considering the widespread use of blended cements in Europe and Japan, it is important to ask why more blended cements are not produced and used in the United States. The reasons for the limited production of blended cements in the U.S. probably include:

a) Combination of low fuel costs and high labor costs have not provided a strong incentive for fuel savings in the past.

b) Abundant supplies of raw materials and relative ease of solid waste disposal have not provided incentives for by-product utilization.

c) Lack of technical information on specific aspects of engineering performance of blended cements based on U.S. materials.

d) Compositional restrictions posed by the ASTM and related standards for blended cements and the limited range of performance tests for cements.

e) Uncertainty about the sustained availability, uniformity and quality of the additives.

f) Capital equipment costs required to produce a more complex product.

Reasons $\mathrm{a}, \mathrm{b}, \mathrm{f}$ and, to some extent, e are essentially economic and will be weakened by the increasing cost of energy. Reasons c, d and, to some extent, e are essentially technical and the development of appropriate technical data is needed to overcome them and facilitate blended cement production and utilization. For example, with regard to reason e, the hydraulic activity of many slags could be substantially upgraded by the introduction of more effective quenching processes. This is because differences in the rates of cooling after molten slag is tapped from a blast furnace at the usual temperature of about 1450 to $1500^{\circ} \mathrm{C}$ result in slags with substantially different reactivities. Slowly cooled slag, called air cooled slag, solidifies into a dense material with a crystalline structure much like that 
of a natural igneous rock [18]. This material, which usually has a high degree of crystallinity, is of little value as a constituent of blended cement. It is, however, useful as aggregate. If the molten slag is cooled more rapidly in the presence of a controlled amount of water, foamed or expanded slag results. This has a high porosity and, because its bulk density is low, it is used as lightweight aggregate. Slag which is very rapidly quenched in a large excess of water solidifies into small glassy granules. Rapid quenching inhibits crystallization and the slag usually retains sufficient reactivity to be a valuable constituent of blended cements. Granulated slag is the only suitable form of slag for use in the manufacture of slag blended cements. Although its use in cement represents a high value use of slag, less than 0.5 million tons $\left(4.54 \times 10^{8} \mathrm{~kg}\right)$ of slag are granulated for this purpose in the U.S. per year [3]. It appears that steel producers have been reluctant to invest in granulation facilities, perhaps because of the small and uncertain market which presently exists for this product.

In the following sections, the geographical limitations on the availability of fly ash and slags for use in blended cement manufacture will be discussed, as will the limitations due to ASTM standards. Steps which might be taken to overcome the latter will then be explained.

\subsection{Geographical Limitations to the Utilization of Slag and Fly Ash in Cement}

Clearlv. increased manufacture of blended cements will require the reactive additives to be shipped economically to the cement plants. Thus, table 6 indicates the geographic distribution of the coal burned by utilities in 1965 [19]. The amount of ash produced in each area may be assumed to be about $10 \%$ of the weight of coal burned. As this table shows, the amount of ash produced is widely distributed suggesting that transportation costs from the utilities to the cement producers will often be low. Of course, not all cement producers are in a position to benefit equally from the fly ash produced, nor are all utilities in a position to benefit from ash utilization in cement manufacture. However, many are and the quantity of fly ash blended cement produced could probably be substantially increased before serious transportation limitations occurred. 
Geographical Area States

New England

Middle Atlantic

East North Central

West North Central

South Atlantic

East South Central

West South Central

Mountain

Pacific
(ME, NH, VI, MA, RI, CT)

$(\mathrm{NY}, \mathrm{NJ}, \mathrm{PA})$

$(\mathrm{OH}, \mathrm{IN}, \mathrm{II}, \mathrm{MI}, \mathrm{WI})$

(MN, IA, MO, KS, NE, SD, ND)

(MD, DE, VA, WV, NC, SC, GA, FL)

(MS, AL, TN, KY)

(LA, AR, TX, OK)

(NM, AZ, NV, CO, UT, WY, MI, ID)

$(C A, O R, W A)$
8,207

Coal Burned, tons $\times 10^{3} /$ year

40,553

83,570

13,749

39,502

33,902

10

6,644

None

One ton is equivalent to approximately $907 \mathrm{~kg}$. 
The production of blast furnace slag is much more localized than that of fly ash. Of the 25 million tons $\left(2.3 \times 10^{10} \mathrm{~kg}\right)$ produced in 1972 , about 5.3 million $\left(4.8 \times 10^{9} \mathrm{~kg}\right)$ were produced in Ohio, 6 million $\left(5.4 \times 10^{9} \mathrm{~kg}\right)$ in Pennsylvania, and a total of $5.3 \mathrm{million}$ $\left(4.8 \times 10^{9} \mathrm{~kg}\right)$ in Illinois, Indiana and Michigan. The remaining $8.4 \mathrm{million}$ tons $\left(7.6 \times 10^{9}\right.$ kg) were produced in 11 other states [3]. Figure 1 shows the distribution of cement plants and blast furnaces. With only a few exceptions slag is produced within a relatively short distance (150 miles or less) from a cement plant. This seems to indicate that the minimal utilization of slag by the cement industry is not a result of excessive transportation distances.

\subsection{Specification Limitations to Slag and Fly Ash Utilization in Cement}

Even if there are no major technical problems in making blended cements which perform well, the lack of appropriate standard tests and specifications would hinder the acceptance of these materials. As one example, ASTM specifications for blended cements, specifically ASTM C595-74 [5] tend to be restrictive with regard to the quantities of fly ash pozzolans or blast furnace slag which can be used. This standard only provides for blended cements containing 15 to $40 \% \mathrm{fly}$ ash or a minimum of $25 \%$ blast furnace slag, even though experience in other countries has shown that greater or lesser quantities of these materials could be added depending on the engineering performance desired from the blended cement. For example, a blended cement containing relatively small amounts, perhaps 5-15\%, of fly ash or ground slag, may give a concrete of higher early strength than one made with a portland cement. The slag or fly ash, because of their reactivity, might also contribute additional strength to the system at later ages. In spite of this, the present lack of standard specifications for such cements provides an obstacle to their manufacture and use. While there is discussion about the possibility of modifying the ASTM blended cement specifications, to permit addition levels outside the presently specified ranges, no action has yet been taken. 


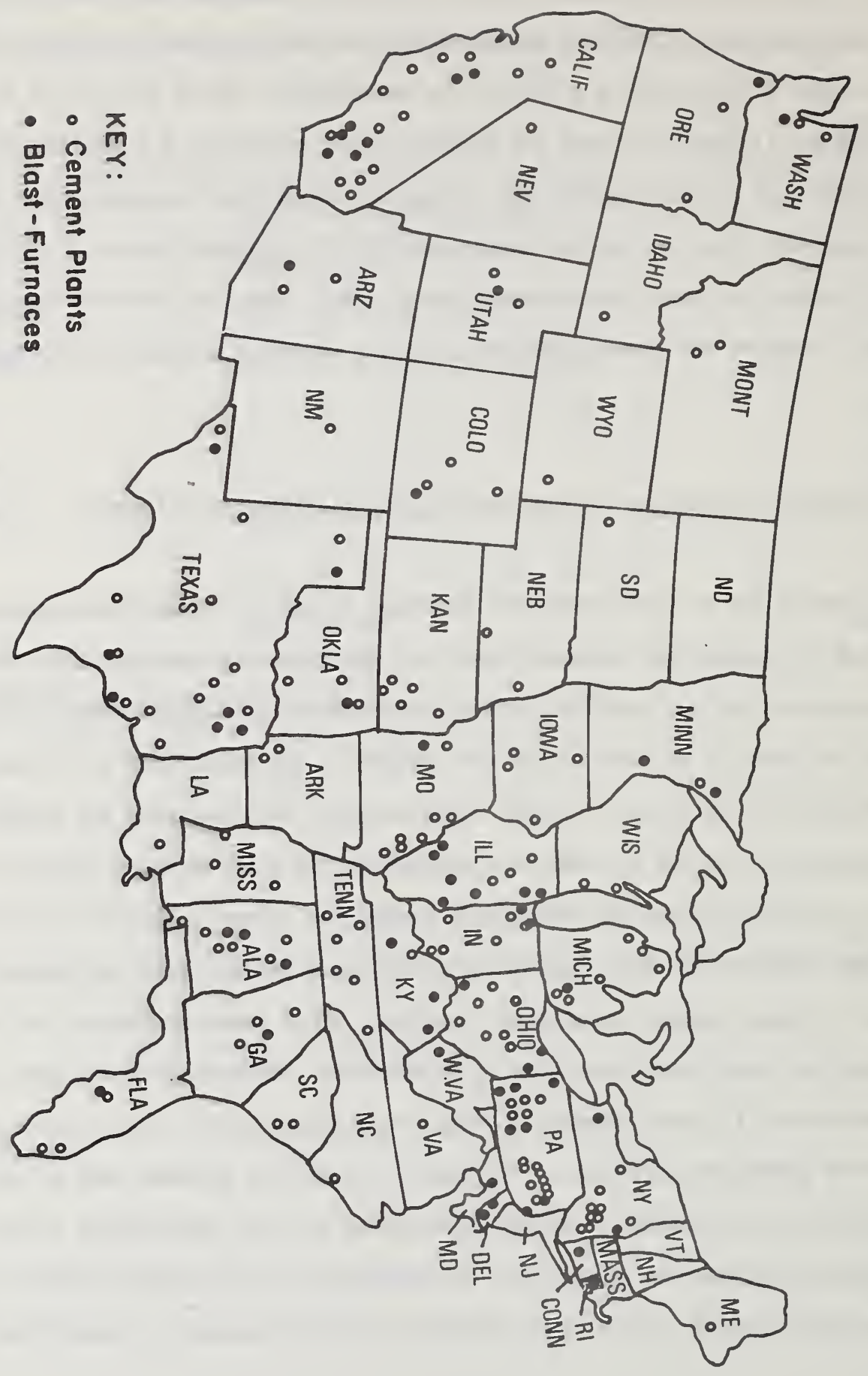

FIGURE 1. The geographic distribution of blast furnaces and cement production facilities [1] . 
As an example of the need for new standard tests, the need for a standard test to determine hydraulic reactivity of slags may be mentioned. The reactivity of a slag, hence its suitability for incorporation into a blended cement, depends on its chemical composition and the rate at which it was quenched from the molten state. The quenching rate influences both the composition and the fraction of the amorphous or glassy material present. Judged by the compressive strengths of slag-portland cement mixtures, there may be an optimum composition of slag glass of about 52\% $\mathrm{CaO}, 33 \% \mathrm{SiO}_{2}$ and $15 \% \mathrm{Al}_{2} \mathrm{O}_{3}$ [20]. While ASTM Standard C595-74 does not place compositional requirements on slags for use in cement [5], foreign specifications generally contain formulas, such as $\left(\mathrm{CaO}+\mathrm{MgO}+\mathrm{Al}_{2} \mathrm{O}_{3}\right) / \mathrm{SiO}_{2} \geq 1$ [2l], by which the suitability of a particular slag may be judged. While convenient to use, a specification of this type will usually be more restrictive than a performance based specification such as the pozzolanic activity index [5] which may be applied to fly ash. However, present ASTM standards do not provide either type of specification for slag. Thus, a potential user does not have an accepted method by which slag may be evaluated for suitability for use in cement manufacture.

Fly ashes to be used in blended cements are, however, subject to compositional restrictions. ASTM Standard C618-73 requires that the minimum combined amounts of $\mathrm{SiO}_{2}, \mathrm{Al}_{2} \mathrm{O}_{3}$ and $\mathrm{Fe}_{2} \mathrm{O}_{3}$ be at least 70 \% of the weight of the ash [22]. This precludes utilization of many fly ashes even though it has not been adequately demonstrated that those which do not conform to these compositional requirements will necessarily result in unsatisfactory blended cements. For example, this compositional requirement precludes the use of many fly ashes from the low sulfur western coals which are being used in rapidly increasing amounts due to environmental limitations on $\mathrm{SO}_{2}$ emissions. Ash from these coals is high in Ca0, with contents often exceeding $30 \%$. While the performance of blended cements containing these ashes must be shown to be satisfactory before their use is allowed, the ashes should not be unnecessarily precluded by the $70 \%$ composition requirement alone.

While the oxide composition requirement may be too restrictive on the loss, ignition requirement for fly ash may not be sufficiently restrictive. Because unburned carbon always occurs in intimate mixture with fly ash, a maximm weight loss on ignition of $12 \%$ fly ash is specified by ASTM Standard C618-73 [22]. However, this requirement does not ensure the 
exclusion of carbon contents which may result in a large or variable consumption of chemical admixtures for concrete. These admixtures, which are usually organic, are used for set regulation, air entrainment, or water reduction. Apparently, these admixtures are adsorbed on the surfaces of the carbon particles thereby reducing their effectiveness. From an esthetic standpoint, high carbon ash may impart an undesirable color to concrete. Decreasing permitted ignition losses to a lower level could aid in the elimination of this problem. This could be done directly by specifying a lower maximm ignition loss or, indirectly, through the development of appropriate performance criteria for admixture consumption.

From these examples, it can be seen that new standard tests and specifications could facilitate the selection of materials for use in blended cements and contribute to confidence in the performance of the blended cement themselves. In the following section, consideration is given to specific performance tests.

\subsection{Standard Tests for Blended Cements}

Most of the performance tests and specifications currently applied to blended cements were originally developed for portland cements. In many cases, they provide adequate basis for the evaluation of blended cements. However, in other cases, they are unduly restrictive and do not adequately consider the differences between these types of materials. The development of tests which objectively evaluate the performance of blended cements is crucial to the facilitation of the acceptance of these materials.

Important areas in which new or improved standard tests, specifications and/or research data are needed are:
1) soundness
2) resistance to attack by sulfates
3) reactivity with alkali-susceptible aggregates
4) freeze-thaw durability
5) admixture performance
6) fly ash or slag content of blended cement 

7) strength gain
8) pozzolan and slag reactivity
9) protection of reinforcing steel against corrosion.

Brief outlines of the reasons why new or improved performance tests and specifications are needed are given in the following sections.

\subsubsection{Soundness}

Soundness is the ability of a cement paste, mortar or concrete to withstand intermal stresses generated during the cement hydration without cracking. Unsoundness, when it occurs, is usually due to slow hydration of dead-burned CaO and MgO in the cement after the cement paste matrix has hardened. The products of both hydration reactions have significantly larger volumes than the compounds from which they are formed. These increases in volume result in internal stresses which may be reflected as an expansion or, if sufficiently large, a total disruption of the paste.

The autoclave expansion test developed for detecting unsoundness in portland cements, ASTM C151-74a [5], is a good, though perhaps overly severe, test for this property. This test is also applied to blended cements although in this case there is some uncertainty as to whether it provides adequate protection against unsoundness occurring in use. This is because there are indications that the hydration of Mgo in the presence of fly ash under autoclave conditions may result in smaller expansions than occur under field conditions. This may be attributed to the formation of comoounds which do not occur in field conditions [23]. Further study in this area is warranted to assess the validity of this test. Alternatively, if blended cements do exhibit diminished expansive tendencies, an increase in the allowable MgO limit above the current 5\% (ASTM C595-74 [5]) may be justified. This could permit the use of readily available higher Mgo limestones with possible savings in mining and transportation costs and conserve low magnesium limestones for purposes for which they are essential.

The results of the autoclave tests on any cement are probably effected by the strength developed in the specimen during the prescribed curing prior to initiating the test. This 
may cause an unnecessary bias against blended cements containing high percentages of pozzolan or slag since the strengths of these materials are usually lower than those of portland cements after the standard one day cure. The influence of preautoclave strength on autoclave expansion should also be investigated. The expansion which takes place in the autoclave is a result of internal stresses which exceed the strength of the material, and autoclaving probably accelerates the reactions causing development of internal stresses more than those responsible for strength development. It may therefore be beneficial to permit a given strength to be attained prior to test initiation.

\subsubsection{Resistance to Attack by Sulfates}

There is strong evidence that blended cements tend to show higher resistance to sulfate attack than portland cements $[14,15]$. Sulfate attack of concrete may lead to disruptive expansion of the hardened cement paste matrix of the concrete and reduce the useful life of concrete structures exposed to sulfate conditions. Sources of sulfate include drainage water, ground water and sea water. While the actual mechanism is not fully understood, attack may result from reaction of soluble sulfates with the calcium hydroxide and hydrated alumina-containing phases formed during cement hydration to form gypsum and highly hydrated calcium aluminosulfate compounds having large specific volumes. Susceptibility to these reactions appears to be reduced in blended cements, possibly because of reactions between the calcium hydroxide and pozzolan or slag. In spite of their probably advantages, the use of blended cements, rather than Type $\mathrm{V}$ portland cement, where high sulfate resistance is required is virtually excluded since there is no standard tests for establishing sulfate resistance.

The only standard sulfate resistance test currently available, ASTM C452-68 [5], involves the measurement of expansion of mortar. In this test, calcium sulfate is mixed with dry cement prior to the addition of water. Because a substantial degree of reaction occurs at early ages before the mortar has developed its full strength, this test is not representative of field conditions. Under normal exposure conditions, sulfate attack probably occurs by the slow diffusion of sulfate-containing water into the concrete after the cement has undergone a substantial degree of hydration. A test which more closely simulates this behavior would 
be more realistic as a basis for selection of sulfate resistant cements. The availability of such a test would facilitate the selection of any suitable cement, whether blended or portland, for use where sulfate resistance is important.

\subsubsection{Reactivity with Alkali-Susceptible Aggregates}

The reaction between alkalis present in cement and certain types of stone aggregate used in concrete sometimes leads to the formation of highly hydrated alkali silicates. The formation of these compounds can result in a disruptive expansion of concrete. The mechanism and kinetics of these reactions are not well understood and, depending on the nature of the aggregate and the exposure conditions, expansion may manifest itself at an early age or only after several years. Additions of pozzolanic fly ash to a cement or concrete can reduce the expansive potential of this reaction between alkalis and aggregate [24]. However, the usual approach to reducing the likelihood of alkali-aggregate reaction is to specify low alkali portland cements.

Current specifications, ASTM C441-69 and C227-71 [22], for cements to be used with reactive aggregates appear to be unnecessarily restrictive in that they apply only to portland cement and do not permit beneficial interactions between the ingredients of the concrete to be taken into account. It would be beneficial if performance specifications could be developed which would take into account both the alkali absorption capacity of the pozzolan and the alkali content of the cement. Such a specification could provide flexibility in the use of each component in a composite such as concrete. This could be of value to the cement industry in that it would make it possible for the alkali contents of some cements to be increased. This would allow the use of readily available raw materials with alkali contents higher than those currently permitted and reduce the need to discard large quantities of high alkali kiln dust. These changes would aid in the conservation of both materials and energy. Energy would be conserved since kiln dust already has a significant energy input from the grinding and heat requirements of cement production and its reintroduction into the system would alleviate a substantial disposal problem. 


\subsubsection{Freeze-Thaw Durability}

In many areas of the country, concrete is subject to damage by freezing and thawing. This must be taken into account when designing the concrete and it may influence the selection of the concrete. Thus, when blended cements are tested according to ASTM C666-73 [22], the standard method for measuring the freeze-thaw durability of portland cement concretes, inferior resistance is usually observed [25]. This is probably because test. initiation after only a short curing period does not make proper allowance for the generally lower rate of strength development of blended cements. Freeze-thaw studies, when initiated after longer curing periods, have indicated that blended cements, due to development of strengths equivalent or superior to those of portland cements, also develop superior resistance to freezing and thawing [26].

Studies are needed to determine the rate of development of freeze-thaw resistance in blended cement as this directly relates to seasonal concrete placement practices. If substitution between them is to be facilitated, comparison of portland and blended cements on the basis of equivalent age should be supplanted or supplemented by the development of more realistic basis of comparison, such as equivalent strength or predicted strength at time of first freeze.

\subsubsection{Admixture Performance}

A substantial and increasing fraction of the concrete placed in the U.S. contains chemical admixtures which are used to regulate set times, entrain air or reduce water requirements. Set regulation is used to delay initial set times extending the time available for finishing; air entrainment, the entrapment of small air voids in the cement paste, is used to improve resistance to freeze-thaw damage; water requirement reduction leads to a reduction in the porosity of the matrix of the hardened concrete with attendent benefits of increased strength and chemical resistance. Blended cements containing fly ash contain small but variable amounts of active carbon which is present in fly ash due to incomplete combustion of coal from which it was formed. This carbon absorbs chemical admixtures and tends to diminish their effectiveness. Since this effect does not vary in a consistent way with the 
absolute carbon content of the cement, admixture response is difficult to predict. Methods for determining the absolute amount and surface area of the carbon in fly ash may need to be developed in order to more fully understand this phenomenon and, if possible, to establish a standard testing procedure.

\subsubsection{Fly Ash and Slag Contents of Blended Cements}

The uniformity of a cement is important to the user. Uniformity of a blended cement depends on both cement content and the fineness and composition of the additive material. At present no standard tests are available for the analysis of a blended cement for its constituents. Tests for the determination of the portland cement clinker and additive contents and their compositions are therefore needed. The availability of such tests would make it possible to assess the uniformity of blended cements both from the standpoint of cement composition and additive characteristics. This information could be important to the manufacturer and the user in alerting them to changes in quality and in establishing the causes of unexpected variations in performance.

\subsubsection{Strength Gains of Blended Cement Concretes}

In considering the substitution of a blended cement for a portland cement, it must be recognized that the two cements may have different rates of strength gain and that the differences in the effects of temperature on strength gain may be substantial. One approach that holds promise in the development of criteria to predict strength gain in cement in general and blended cement in particular is that represented by the maturity concept. Development of this concept involves modeling the cement curing process by relating the time-temperature history to strength gain while including such variables as humidity, cement composition and section thickness. An approach of this type is needed in considering for possibilities for substitution of blended cements for portland cements since blended cements show strength development characteristics which have a higher dependence on curing conditions. This approach would be of practical benefit to the construction industry by providing a rational basis for choosing the proper cement for a given application and in aiding the prediction of form removal times on the work site. 


\subsubsection{Pozzolan and Slag Reactivity}

Pozzolanic reactivity is a measure of the ability of a pozzolan to combine with calcium hydroxide, such as that liberated by hydrating cement, to form products with cementing value. An improved test by which this reactivity may be measured requires development. While tests which measure the rate of lime consumption by fly ash and other pozzolans exist, a test which allows correlation of reactivity with strength does not. A lime consumption test may not always be valid because calcium hydroxide may react with compounds present in a pozzolan to form products which do not contribute appreciably to strength development. In general, it appears that improved methods for assessing the pozzolanic value of fly ashes could assist in the selection of $f l y$ ashes for use in blended cements. The development of a suitable means by which slag reactivity may be measured also requires development as was discussed in section 3.2 .

\subsubsection{Protection of Reinforcing Bars from Corrosion}

The effectiveness of blended cement concretes in protecting steel reinforcing bars from corrosion must be taken into account in the substitution of blended cements for portland cements. Normally steel is passive towards corrosion when in portland cement concrete because of the highly basic environment ( $\mathrm{pH}$ of about 12.5 [27]); however, aggressive agents, such as chloride ions, are able to depassivate steel and thereby promote its active corrosion [28]. A small amount of corrosion of the steel may cause the spalling and cracking of concrete and result in the need for expensive repairs. For example, the annual national cost of repairing and replacing concrete bridge decks because of such damage has recently been estimated by the Federal Highway Administration to be more than $\$ 200$ million. Furthermore, other reinforced concrete structures, particularly parking garages, piers, and buildings located near the ocean, are subject to damage due to corrosion of embedded steel reinforcement.

In the next two decades, the amount of shoreline and offshore concrete construction, especially for nuclear reactors and oil wells, will substantially increase. Therefore, it is anticipated that prevention of corrosion of steel reinforcement in concrete will become increasingly important. 
The extent of the use of blended cements in reinforced concrete construction will, to some extent, depend on the ability of blended cement concretes to protect steel reinforcement from corrosion. More information is needed about this ability since there appear to be at least two opposing factors: blended cement concretes containing fly ash may have lower pH's than concretes with normal portland cements [30], but they also tend to be less permeable to the migration of chloride ions and, on this account, tend to provide better protection to the reinforcing steel than portland cement concretes [31]. Better protection may also be provided because fly ash blended cement concretes seem to be less susceptible to shrinkage cracking than portland cement concretes [32].

Many of the environmental factors which accelerate the corrosion of steel in concrete have been studied. However, the relative effects of different types of cements on the rates of corrosion have received little attention. Furthermore, no ASTM or other standard test method exists for comparing the corrosion protection provided by different concrete including those containing different cements. The development of a standard corrosion test would be beneficial in evaluating the corrosion protective qualities of all types of hydraulic cements and, specifically, in comparing blended and portland cements.

\section{BASIC RESEARCH REQUIREMENTS}

Additional research will be required to provide a sound basis for the development of the standard tests and specifications needed to facilitate substitution between blended and portland cements. For the most part these areas relate to understanding the reactivity of the additives in blended cements and the mechanisms of degradation of portland and blended cement concretes. These areas are:

1) Mechanisms of fly ash and/or slag-cement interaction

2) Influence of absolute fly ash composition and of composition variability within the individual ash particles

3) Methods of accelerating and/or activating fly ash and slag to produce cements exhibiting more rapid gains in strength. 
4) Methods of modifying slag crystallization through composition and/or nucleation inhibitors

5) Mechanisms of sulfate attack

6) Mechanisms of alkali-aggregate reaction

7) Influence of microstructure including porosity, surface area, morphology, and distribution of reaction products on strength and durability

8) Determination of the temperature dependence on the reactivity of blended cements and their engineering properties.

\section{SUMMARY}

The substitution of blended cements for portland cements appears to be attractive from the standpoint of energy conservation. The materials most suitable for use with portland cement clinker in blended cement manufacture are fly ash and blast furnace slags. Fly ash is generated as fine particles and requires little or no processing prior to its introduction into the cement manufacturing process. Blast furnace slag, on the other hand, does require special processing such as granulation to develop its full reactivity. Both blast furnace slag and fly ash are generated in large quantities and the availability of these materials to cement plants does not appear to be a factor which would severely limit their use in this way. However, a more detailed analysis would be required to properly assess these limitations.

The limitations of the current ASTM and related standard specifications covering blended cements along with the need for additional durability and engineering performance data on these materials appears to present significant obstacles to their production and utilization. Standard specifications should be modified to include slag and fly ash addition levels not currently covered by the standards. Composition requirements could in many cases be supplanted by performance based specifications. Durability and performance data for blended cements need to be developed as a basis for standard tests and specifications to further define the advantages and limitation to the utilization of blended cements, and to allow for their appropriate substitution for portland cements. 


\section{REFERENCES}

1. Energy Conservation Potential in the Cement Industry, FEA Conservation Paper \#26, 1975.

2. The Conference Board, Energy Consumption in Manufacturing, Ballinger Publ., Cambridge, Mass., 1974.

3. Bureau of Mines Minerals Yearbook, 1972.

4. U.S. Industrial Outlook 1975, Dept. of Commerce, 1975.

5. "1974 Annual Book of ASTM Standards", Part 13, ASTM, Philadelphia, Pa.

6. All values are from Plastics and Rubber Weekly, September 6, 1974 .xcept where noted.

7. "The Costs of Purchased Fuels and Electric Energy by Industry", Economic Stabilization Program, Cost of Living Council, December 26, 1973.

8. W. Gutt, The Use of By-Products in Concrete, Building Research Establishment Current Paper 53/74 (1974).

9. Cembuream, Bull. No. 57, 1974.

10. V. I. Satarin, "Slag Portland Cement", Proc. of the Sixth International Symposium on the Chemistry of Cement, Moscow 1974.

11. Bu. Reclamation Concrete Lab Rept. No. C-980, 1961.

12. K. Guida, Ash Utilization, Bu. Mines IC 8640, 1974, p. 58.

13. R. J. Elfert, Ash Utilization, Bu. Mines IC 8640,1974, p. 88. 
14. F. M. Lea, The Chemistry of Cement and Concrete, Chem. Publ. Co., N.Y. 1971.

15. G. L. Kalousek, L. C. Porter and E. J. Benton, Cement and Concrete Research 2, 79 (1972) .

16. E. A. Abdun-Nur, Fly Ash in Concrete, Chicago Fly Ash Co., Oct. 1959.

17. Ash Collection and Utilization 1974, Ash at Work, Vol. 7, No. 3, 1975.

18. A. R. Lee, "Blast Furnace and Steel Slag", John Wiley, N.Y., 1975.

19. C. E. Bracket, in Fly Ash Utilization, Bu. Mines IC 8348 (1967) p. 20.

20. T. Tanaka and J. Jamani, Zement-Kalk-Gips 11, 50 (1968).

21. German Specification DIN 1164, 1967.

22. Annual Book of ASTM Standards, Part 14 Concrete and Mineral Aggregates, ASTM Philadelphia (1974).

23. J. Rosa, Zement-Galk-Gips 9 , 460 (1965).

24. U. S. Army Engineers Waterways Expt. Station Tech. Rept. 6-627, June 1963.

25. A. G. Timms and W. E. Grieb, Public Roads 29, 142 (1957).

26. R. E. Davis, et al, J. Am. Concrete Inst. 37, 281 (1941).

27. J. D. Mozer, A. C. Bianchini and C. E. Kesler, J. Am. Concrete Inst. 62, No. 8, 90 (1965) .

28. J. E. O. Mayne, J. W. Menter, and M. J. Pryor, J. Chem. Soc. 3229 (1960). 
29. H. Abe, S. Nagatabi and R. Tusbayama, Discussion of Fly Ash and Fly Ash Cement by M. Kokubu, p. 105, Volume IV, Proceedings of the Fifth International Symposium on the Chemistry of Cement, Tokyo, 1968.

30. R. E. Davis, J. Amer. Concrete Inst. 46, No. 1, 377 (1950).

31. R. F. Blanks, J. Amer. Concrete Inst., 46, No. 5, 701 (1950). 



\begin{tabular}{|c|c|c|c|}
\hline $\begin{array}{l}\text { U.S. D. PT. OF COMM. } \\
\text { BIBLIOGRAPHIC DATA } \\
\text { SHEET }\end{array}$ & $\begin{array}{l}\text { 1. PUIBLICATTION OR REEPORT NO. } \\
\text { NBSIR } 76-1008\end{array}$ & $\begin{array}{l}\text { 2. Gov't Accession } \\
\text { No. }\end{array}$ & 3. Recipient's Accession No. \\
\hline \multicolumn{3}{|l|}{ 4. TITLE AND SUBTITLE } & 5. Publication Date \\
\hline \multirow{2}{*}{\multicolumn{3}{|c|}{$\begin{array}{l}\text { Energy Conservation Through the Faciliation of Increased } \\
\text { Blended Cement Use }\end{array}$}} & February 1976 \\
\hline & & & 6. Performing Organization Code \\
\hline \multicolumn{3}{|c|}{$\begin{array}{l}\text { 7. AUTHOR(S) } \\
\text { Paul Wencil Brown, James R. Clifton, Geoffrey Frohnsdorff }\end{array}$} & 8. Performing Organ. Report No. \\
\hline \multicolumn{3}{|c|}{ 9. PERFORMING ORGANIZATION NAME AND ADDRESS } & 10. Project/Task/Work Unit No. \\
\hline \multicolumn{3}{|c|}{$\begin{array}{l}\text { NATIONAL BUREAU OF STANDARDS } \\
\text { DEPARTMENT OF COMMERCE } \\
\text { WASHINGTON, D.C. } 20234\end{array}$} & 11. Contract/Grant No. \\
\hline \multirow{2}{*}{\multicolumn{3}{|c|}{$\begin{array}{l}\text { 12. Sponsoring Organization Name and Complete Address (Street, City, State, ZIP) } \\
\text { Energy Research and Development Administration } \\
20 \text { Massachusetts Avenue } \\
\text { Washington, DC } 20545\end{array}$}} & $\begin{array}{l}\text { 13. Type of Report \& Period } \\
\text { Covered Interim } \\
\text { July } 1 \text { - December } 1975\end{array}$ \\
\hline & & & 14. Sponsoring Agency Code \\
\hline \multicolumn{4}{|l|}{ 15. SUPPLEMENTARY NOTES } \\
\hline \multicolumn{4}{|c|}{$\begin{array}{l}\text { 16. ABSTRACT (A 200-word or less factual summary of most significant information. If document includes a significant } \\
\text { bibliography or literature survey, mention it here.) }\end{array}$} \\
\hline \multicolumn{4}{|c|}{$\begin{array}{l}\text { About 95\% of the cement produced in the United States is portland cement and its } \\
\text { manufacture requires about } 2 \% \text { of the energy consumed annually in the nation's industrial } \\
\text { processes. The production of blended cements containing substantial amounts of fly ash } \\
\text { or blast furnace slag and their substitution for portland cement appears attractive from } \\
\text { the standpoint of energy conservation. While production and utilization of blended } \\
\text { cements in other industrialized countries is extensive, blended cements account for less } \\
\text { than l\% of the total cement production in the U.S. The reasons for the small U.S. } \\
\text { production of blended cements are discussed in the contexts of standards revision and } \\
\text { the need for the development of additional data as a basis for this revision. }\end{array}$} \\
\hline
\end{tabular}
the need for the development of additional data as a basis for this revision.
17. KEY WORDS (six to twelve entries; alphabetical order; capitalize only the first letter of the first key word unless a proper name; separated by semicolons)

Blast furnace slag; blended cements; energy conservation; fly ash:

\begin{tabular}{|c|c|c|}
\hline 18. AVAILABILITY & $\begin{array}{l}\text { 19. SECURITY CLASS } \\
\text { (THIS REPORT) }\end{array}$ & 21. NO. OF PAGES \\
\hline [ For Official Distribution. Do Not Release to NTIS & UNCL ASSIF IED & 27 \\
\hline 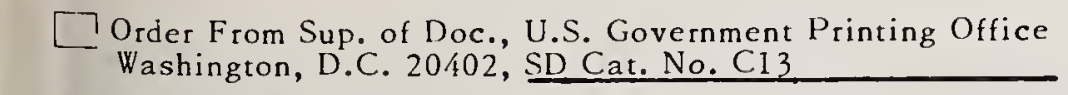 & $\begin{array}{l}\text { 20. SECURITY CLASS } \\
\text { (THIS PAGE) }\end{array}$ & 22. Price \\
\hline $\begin{array}{l}\mathrm{X}, \text { Order From National Technical Information Scrvice (NTIS) } \\
\text { Springfield, Virginia } 22151\end{array}$ & UNCLASSIFIED & $\$ 4.00$ \\
\hline
\end{tabular}


